\title{
Cost-Effectiveness of Converting Fish Waste into Liquid Fertilizer
}

\author{
Joong Kyun Kim* \\ Department of Biotechnology and Bioengineering, Pukyong National University, Busan 608-737, Korea
}

\begin{abstract}
To determine the cost-effectiveness of converting fish waste into liquid fertilizer, this study analyzed the production of $3 \mathrm{~L}$ of liquid fertilizer from the fermentation of fish waste. The total product cost of the fertilizer was calculated to be $\$ 165.26$ for a onebatch operation. If the seed culture was repeated five times, the total product cost could be reduced to $\$ 36.39 / \mathrm{L}$. According to this analysis, the reutilization of fish waste as liquid fertilizer was not particularly economically attractive at present, and plant-scale production would be necessary for commercialization. This is the first cost-effectiveness analysis of the bioconversion of fish waste into liquid fertilizer.
\end{abstract}

Key words: Cost-effectiveness, Bioconversion, Fish wastes, Liquid fertilizer

\section{Introduction}

Fish consumption continues to increase steadily worldwide and seafood is gaining in popularity because of its health benefits. At the same time, large amounts of fish waste are being generated, mostly from the industrial processing of fish. These large quantities of fish waste have not been utilized efficiently, and the disposal of fish waste can have large negative impacts on local environments. Unutilized fish waste is often disposed of by landfill or incineration, or by dumping into the sea. Therefore, there is an urgent need to find ecologically acceptable means for reutilizing fish waste.

Conventional methods for reutilization include ensilation and the production of high-protein meal used in animal feeds (Faid et al., 1997). Composting has also been suggested as a viable solution to the problem of fish waste disposal (Liao et al., 1997), and fermentation has been studied as a means of producing fish protein for use in animal feed (Hassan and Heath, 1986; Faid et al., 1997). Yeasts and/or lactic acid bacteria are used to ferment fish waste and to remove odor. Furthermore, shrimp waste ensilation is conducted as a preservation method and to allow for the recovery of value-added byproducts such as chitin (Cira et al., 2002) and cartenoids (Sachindra et al., 2007). In recent years, the use of the acid hydrolysis of fish waste has been studied to produce low-cost nutrients for the production of lactic acid (Gao et al., 2006), and low-cost protein sources have been produced by ensiling hydrolyzed fish viscera to obtain an adequate medium for lactic acid bacteria (Vázquez et al., 2008).

Some fish waste is also reutilized for fishmeal production (Keller, 1990; Hall, 1992); however, this process is costly and the heat required for drying makes the fish meal less digestible (Yamamoto et al., 2005). Therefore, new biological-fermentation techniques have been proposed to process fish waste inexpensively (Yamamoto et al., 2004, 2005), since some additional waste can be generated during the fishmeal manufacturing process (Yano et al., 2008). Yamamoto et al. (2004) presented a new low-cost fermentation technique using Aspergillus awamori that could be applicable to fish waste processing, and Yano et al. (2008) reported a fermentation technique that improves the quality of fishmeal from lipid-rich fish waste. The fast fermentation of squid-processing by-products for low-salt fish sauce production has been also reported (Xu et al., 2008).

Organic wastes have been found to contain compounds capable of promoting plant growth (Day and Katterman, 1992) and seafood processing wastewater does not contain known
Open Access http://dx.doi.org/10.5657/FAS.2011.0230

This is an Open Access article distributed under the terms of the Creative Commons Attribution Non-Commercial License (http://creativecommons. org/licenses/by-nc/3.0/) which permits unrestricted non-commercial use, distribution, and reproduction in any medium, provided the original work is properly cited. pISSN: 2234-1749 eISSN: 2234-1757
Received 12 May 2011; Revised 29 June 2011; Accepted 11 August 2011

*Corresponding Author

E-mail: junekim@pknu.ac.kr 
toxic or carcinogenic materials, unlike other types of municipal and industrial effluents (Afonso and Bórquez, 2002). Considering these findings, the fermented broth of fisheries waste could be a valuable resource for agriculture. Recently, some studies have examined the reutilization of biodegraded fisheries-waste products as liquid fertilizer (Kim and Lee, 2009; Kim et al., 2010; Dao and Kim, 2011). In Korea, many restaurants specialize in sliced raw fish, and large amounts (approximately 2,100 t/day) of fish waste are generated every day (Kim et al., 2010). For practical reutilization of this fish waste as liquid fertilizer, the feasibility of commercialization must be evaluated. Therefore, in this study, the cost-effectiveness of the bioconversion of fish waste into liquid fertilizer in a 5-L reactor was demonstrated.

\section{Materials and Methods}

\section{Microorganisms}

This study used five potential fish-waste-degrading bacteria isolated from the viscera of earthworms: Brevibacillus agri, Bacillus cereus, two species of Bacillus licheniformis, and Brevibacillus parabrevis (Kim et al., 2010). Each strain was separately cultivated and combined on a 1:1 even weight basis, and the mixed cells were used as an inoculum for the 5 -L reactor experiment. Each pure strain was maintained on a $1.5 \%$ nutrient agar plate at $4^{\circ} \mathrm{C}$ until used and was transferred to a fresh agar plate every 2 weeks. At the same time, the potential degrading ability of each pure culture was also examined on $1 \%$ skim milk agar for proteolysis and on $3.215 \%$ spirit blue agar for lipolysis. All agar plates were incubated at $45^{\circ} \mathrm{C}$ until a change in color or a clear zone around each colony appeared explicitly.

\section{Bioconversion of fish wastes into liquid fertilizer}

The scale-up characteristics of fish-waste biodegradation were examined in a 5-L ribbon-type reactor using six ribbontype blades for better mixing effect, as described in a previous study (Dao and Kim, 2011). The fish waste used in this study was collected from a local restaurant specializing in sliced raw fish. The mixture of viscera, heads, tails, and bones was cut to a size of $1 \mathrm{~cm} \times 1 \mathrm{~cm}$ or less and autoclaved at $121^{\circ} \mathrm{C}$ for $20 \mathrm{~min}$. After autoclaving, fish oil was removed from the fish wastes by flowing hot water over the fish wastes under a clean bench. A $2 \mathrm{~kg}$ wet weight portion was introduced into a $5-\mathrm{L}$ reactor after the supernatant was decanted.

The mixed microorganisms $(5,000 \mathrm{mg} / \mathrm{L})$ were inoculated into the reactor filled with sterile fish wastes $(2 \mathrm{~kg})$ and $1 \mathrm{~L}$ distilled water (DW) under aseptic conditions. The reaction temperature and agitation speed of the reactor were maintained at $45 \pm 0.5^{\circ} \mathrm{C}$ and $75 \pm 2 \mathrm{rpm}$, respectively. Air ( $\left.1 \mathrm{~L} / \mathrm{min}\right)$ was passed through a $0.2-\mu \mathrm{m}$ membrane filter paper prior to being introduced into the reactor. Ten-fold diluted 'Antifoam 204' was used when severe foaming occurred during biodegradation. Discharging air was passed through two consecutive 1-L flasks containing $10-\mathrm{N} \mathrm{NaOH}$ to avoid contamination from outer foreign microorganisms. To collect the evaporated water loaded in the discharging air, the two flasks were placed in ice. At each sampling time, the flasks filled with the condensed water were exchanged with fresh ones, and the same amount of sterile DW was supplemented into the reactor to maintain the moisture content of the fish waste (45 to $60 \%$ ) during the bioconversion. Samples were taken periodically from three different locations.

\section{Estimation of the cost of liquid fertilizer production}

The cost of production of liquid fertilizer in a 5 -L reactor was assessed to evaluate the cost-effectiveness of the bioconversion of fish waste for reutilization. Estimation was based on the preparation of microorganisms and fish waste, the biodegradation of fish waste for $96 \mathrm{~h}$, the packing and preservation of the biodegraded product, and a waste-treatment credit. Costs of the transportation of fish waste, electricity, water, labor, bottling, and packing were based on current prices in Korea. The costs of chemicals for culture and preservation were estimated according to the prices offered by Sigma-Aldrich Co. (St. Louis, MO, USA).

\section{Results and Discussion}

The greater part of the suspended fish waste was degraded during the biodegradation in a 5 -L reactor, and the most active biodegradation of fish waste occurred at around $96 \mathrm{~h}$ with the appearance of a pleasant smell. This reaction rate would be retarded without the autoclave pretreatment, since the preservation of fish waste in the restaurant was not adequate to prevent the process of putrefaction. In a previous study (Dao and Kim, 2011), the following results were obtained: a 96-h culture of fish waste medium had comparable fertilizing ability to commercial fertilizers and could be prevented from putrefying for 6 months at room temperature by the addition of $1 \%$ lactate. These findings were based on the estimation of the cost of producing liquid fertilizer from fish waste.

The cost of the liquid fertilizer production was calculated and is tabulated in Table 1. To degrade $2 \mathrm{~kg}$ of fish waste, $15 \mathrm{~g}$ of mixed microorganisms were prepared, and $1.68 \mathrm{~L}$ of liquid fertilizer was finally produced after $96-\mathrm{h}$ biodegradation. The costs of packing and preservation of the culture medium of fish waste as a final product were calculated to be $\$ 0.24$ and $\$ 0.05$, respectively. In this calculation, the period of circulation in the market for liquid fertilizer was assumed to be 6 months (Kim et al., 2010). The total cost of a one-batch operation was calculated to be $\$ 165$.26. In this calculation, installation (e.g., air compressor, reactor, probes) fees were not con- 
Table. 1 Calculation of average costs for one-batch bioconversion of fish wastes into liquid-fertilizer in a 5 - $\mathrm{L}$ reactor

\begin{tabular}{llc}
\hline Category & Cost (\$) per unit & Cost (\$) \\
\hline $\begin{array}{l}\text { Microorganism }(15 \mathrm{~g}) \\
\quad \text { Culture chemicals }(132.6 \mathrm{~g})\end{array}$ & $0.15 / \mathrm{g}$ & 19.89 \\
$\quad$ Cell culture and harvest & & \\
$\quad$ Electricity & & \\
$\quad$ Water & $0.18 / \mathrm{KWh}$ & 70.97 \\
$\quad$ Labor & $1.25 / \mathrm{h}$ & 1.8 \\
Fish wastes (2 kg) & & 37.5 \\
$\quad$ Transportation & $0.02 / \mathrm{kg}$ & \\
Reaction (3-L working volume) & & 0.04 \\
$\quad$ Chemicals & \\
$\quad$ Electricity & $0.15 / \mathrm{g}$ & \\
$\quad$ Water & $0.18 / \mathrm{KWh}$ & 19.48 \\
$\quad$ Labor & $0.12 / \mathrm{L}$ & 0.36 \\
Final culture medium (1.68 L) & $1.25 / \mathrm{h}$ & 15 \\
$\quad$ Bottling and packing & & \\
$\quad$ Preservation (1\% lactate) & $0.14 / \mathrm{L}$ & 0.24 \\
Waste-treatment credit & $2.92 / \mathrm{kg}$ & 0.05 \\
Total & $-0.04 / \mathrm{kg}$ & -0.08 \\
\hline
\end{tabular}

"Electricity includes the use of distilled-water maker, autoclave, clean bench, incubator and centrifuge, ${ }^{+} \mathrm{Chemicals}$ mean $\mathrm{NaOH}$ and antifoaming agent consumed during the reaction, ${ }^{\neq}$Electricity includes the use of air compressor and reactor.

sidered with running costs, since such machinery can be used semi-permanently. As shown in Table 1, the costs (\$130.16) of the preparation of seed microorganisms accounted for $78.8 \%$ of the total cost. In actual operation, the final culture medium containing mixed microorganisms would be used as the seed culture for successive biodegradation under conditions of no contamination, since there was no bacterial antagonist among the five microorganisms used in this study (Kim et al., 2010). Under this situation, the change in the mixed-cell population was reflected by the specific growth rate of each species. As a result, significant changes in cell population would not occur in five successive uses. If the prepared cells are used five times, the total cost is reduced to $\$ 36.39 / \mathrm{L}$. In addition, labor charges can be reduced remarkably when an automatic cellculture system is used, as would be required for plant-scale production. Currently, the prices of the high-quality liquid fertilizers circulated in the domestic market are in the range of $\$ 16.7-41.7 / \mathrm{L}$. This indicates that the production of liquid fertilizer from fish waste is not particularly economically attractive. However, this study did not consider the economic effects of the overall environmental improvement resulting from the treatment of fish waste. Additionally, the cost of disposing of fish waste will increase remarkably after 2012, when the dumping of waste into the sea will be prohibited in Korea according to the London Convention (International Maritime Organization, 2006). As a result, the economic effects are greater than those calculated. Also, large-scale production can further reduce the total cost, since larger installations have advantages resulting from economies of scale (Amigun and von
Blottnitz, 2007). For practical commercialization, plant-scale production has to be undertaken.

\section{Acknowledgments}

This research was supported by a grant (receipt number: 20100576) from Korea Institute of Planning and Evaluation for Technology of Food, Agriculture, Forestry and Fisheries.

\section{References}

Afonso MD and Bórquez R. 2002. Review of the treatment of seafood processing wastewaters and recovery of proteins therein by membrane separation processes: prospects of the ultrafiltration of wastewaters from the fish meal industry. Desalination 142, 29-45.

Amigun B and von Blottnitz H. 2007. Investigation of scale economics for African biogas installations. Energy Convers Manag 48, 30903094.

Cira LA, Huerta S, Hall GM and Shirai K. 2002. Pilot scale lactic acid fermentation of shrimp wastes for chitin recovery. Process Biochem 37, 1359-1366.

Dao VT and Kim JK. 2011. Scaled-up bioconversion of fish waste to liquid fertilizer using a $5 \mathrm{~L}$ ribbon-type reactor. J Environ Manage 92, 2441-2446.

Day AD and Katterman FRH. 1992. Sewage sludge provides plant growth factors in arid environments. J Arid Environ 23, 229-233.

Faid A, Zouiten A, Elmarrakchi A and Achkari-Begdouri A. 1997. Biotransformation of fish waste into a stable feed ingredient. Food Chem 60, 13-18.

Gao MT, Hirata M, Toorisaka E and Hano T. 2006. Acid-hydrolysis of fish wastes for lactic acid fermentation. Bioresour Technol 97, 2414-2420.

Hall GM. 1992. Fish processing technology. In: Fishery By-products. Ockerman HW, ed. VCH Publishers, New York, NY, US, pp. 155192.

Hassan TE and Heath JL. 1986. Biological fermentation of fish waste for potential use in animal and poultry feeds. Agric Wastes 15, 1-15.

International Maritime Organization. 2006. International rules on dumping of wastes at sea to be strengthened with entry into force of 1996 Protocol. IMO Briefing, 22 February 2006 [Internet]. International Maritime Organization, Accessed 13 Nov 2006, http://www.londonconvention.org/documents/lc72/LP.

Keller S. 1990. Making profits out of seafood wastes. In: Specifications for Marine By-products for Aquaculture. Hardy RW and Masumoto T, eds. Alaska Sea Grant College Program, Anchorage, AK, US, pp. 109-120.

Kim JK and Lee G. 2009. Aerobically biodegraded fish-meal wastewater as a fertilizer. Environ Res J 3, 219-236.

Kim JK, Dao VT, Kong IS and Lee HH. 2010. Identification and characterization of microorganisms from earthworm viscera for the conversion of fish wastes into liquid fertilizer. Bioresour Technol 101, 5131-5136. 
Liao PH, Jones L, Lau AK, Walkemeyer S, Egan B and Holbek N. 1997. Composting of fish wastes in a full-scale in-vessel system. Bioresour Technol 59, 163-168.

Sachindra NM, Bhaskar N, Siddegowda GS, Sathisha AD and Suresh PV. 2007. Recovery of carotenoids from ensilaged shrimp waste. Bioresour Technol 98, 1642-1646.

Vázquez JA, Docasal SF, Prieto MA, González MP and Murado MA. 2008. Growth and metabolic features of lactic acid bacteria in media with hydrolysed fish viscera: an approach to bio-silage of fishing by-products. Bioresour Technol 99, 6246-6257.

Xu W, Yu G, Xue C, Xue Y and Ren Y. 2008. Biochemical changes as- sociated with fast fermentation of squid processing by-products for low salt fish sauce. Food Chem 107, 1597-1604.

Yamamoto M, Saleh F and Hayashi K. 2004. A fermentation method to dry and convert Shochu distillery by-product to a source of protein and enzymes. J Poult Sci 41, 275-280.

Yamamoto M, Saleh F, Ohtsuka A and Hayashi K. 2005. New fermentation technique to process fish waste. Anim Sci J 76, 245-248.

Yano Y, Oikawa H and Satomi M. 2008. Reduction of lipids in fish meal prepared from fish waste by a yeast Yarrowia lipolytica. Int J Food Microbiol 121, 302-307. 